\title{
ON THE BRINK OF LAWLESSNESS: THE STATE OF COLLECTIVE SECURITY LAW
}

\author{
Nigel D. White
}

\section{The CONCEPT OF COLLECTIVE SECURITY LAW}

There are many definitions and discussions of what is meant by "collective security." Very generally we can delineate this area of international relations as any collective action designed to defuse situations that endanger the peace or to combat threats to and breaches of the peace.

Using United Nations (U.N.) Charter terminology, collective security can both promote the peaceful settlement of situations that endanger peace (Chapter VI processes) and take action with respect to threats to the peace, breaches of the peace or acts of aggression (Chapter VII action). Much debate, mostly legal, then centers around the meaning of terms such as "threat to the peace," "breach of the peace," and the more judgmental concept of "aggression."

The well-documented ${ }^{3}$ lack of consistency and certainty in the development and application of these terms suggests that the balance between law and politics in this area leans towards the political. If the balance moves significantly towards the political then "the rule-governed character of [collective security] will disappear and, with it, the system's deterrent force.

* Professor of International Organizations, School of Law, University of Nottingham, U.K. This is the footnoted text of the Hilaire McCoubrey memorial lecture given at the University of Hull, May 15, 2002. The Reverend Professor McCoubrey (1953-2000) was Professor of Public International Law at the University of Hull, U.K. His many publications included INTERNATIONAL HuMaNITARIAN LAW (1998); REgIONAL PEACEKEEPING IN THE POST COLD WAR ERA (2000) [with Justin Morris]; THE BLUE HELMETS: LEGAL REgULATION OF UN MILITARY OPERATIONS (1996) with Nigel D. White; INTERNATIONAL ORGANIZATIONS AND CIVIL WaRs (1995) with Nigel D. White; and INTERNATIONAL LAW AND ARMED CONFLICT (1992) with Nigel D. White.

1. See generally George W. Downs, COLLECTIVE SECURTTY BEYOND THE COLD WAR (Michigan Univ. Press 1994).

2. U.N. CHARTER art. 39. 'Aggression' can constitute a crime under international law, giving rise to individual and state responsibility. See id. 'Crimes against peace' were within the jurisdiction of the Nuremberg and Tokyo tribunals. See International Military Tribunal, 41 AM. J. L. 172, 1947 (Nuremberg). Although the International Criminal Court has jurisdiction over the crime of aggression, there has been no agreed definition of the offence. See Rome Statute of the International Criminal Court, July 17, 1998, 37 I. L. M. 999, art. 5. See Constantine Antonopoulos, Whatever Happened to Crimes Against Peace?, 6 J.CoNFL. \& SECURITY L. 33 (2001).

3. Nigel D. White, Keeping the Peace: The United Nations and the MaINTENANCE OF INTERNATIONAL PEACE AND SECURITY, 42-52 (1997). 
It will start to seem like just another context for politics." If the keys that unlock the collective security procedures and machinery are simply political ones then law will struggle to play a profound role in this area. However, it is argued below that this is not necessarily the case - the balance between law and politics is a subtle one. It is true that politics are normally in the ascendancy in this, above all, areas of international law, and also that politics influence the development of international law, but laws, particularly fundamental ones, are not easily swept away by the rise and fall of political tides.

Certainly, there is no inexorable move towards the rule of law in international relations, but with the inception of the U.N. Charter the legal foundations for such a move were laid. The Charter contains the fundamental norm prohibiting the threat or use of force; ${ }^{5}$ and it creates the mechanisms for its enforcement. On occasions the rule of law seems to be enforced by the U.N., the primary example being the unprecedented support for the military action taken against Iraq following its invasion of Kuwait in $1990 .^{6}$ Faltering steps forward have been balanced by regression towards the anarchic situation that preceded the U.N. Charter. Total regression though has not occurred, for such a collapse is more difficult in the face of the U.N. Charter, a document that has been accepted by many as the constitution of the international community. ${ }^{7}$

Nevertheless, law at this primary constitutional level is under the greatest political pressure. Even relatively clear terms such as "breach of the peace," while retaining their core certainty, have been applied selectively, while other terms, such as "threat to the peace," have an inherent ambiguity, deliberately chosen so as to allow a significant amount of discretion. The amount of discretion, however, is debated, ${ }^{8}$ with there being strong contentions that even determinations of threats to the peace by the Security Council are subject to law. It has been suggested that legal principles applicable include the concept

4. Martti Koskenniemi, The Place of Law in Collective Security, 17 MiCH. J. INTL. L., 455,464 (1996).

5. See U.N. CHARTER art. 2, para. 4.

6. See Pierre-Marie Dupuy, The Constitutional Dimension of the Charter of the United Nations Revisited, 1 MAX PLANCK Y.B. OF U.N. L. 20 (1997).

7. See Rudolf Bernhardt, Article 103 in B. Simma (ed.), THE ChARTER of THE UNITED Nations: A COMmentary (1995); Christian TOMUSChat, THE UnITEd Nations at AGE FIFTY: A LEGAL PERSPECTIVE(1995). But see Gaetano Arangio-Ruiz, The Federal Analogy and U.N. Charter Interpretation: A Crucial Issue, 8 E.J.I.L. 1, 9 (1997); J.E. Alvarez, Constitutional Interpretation in International Organizations in J-M. Coicaud and V. Heiskanen (eds.), THE LEgITIMACY OF INTERNATIONAL ORGANIZATIONS 104, 104-110 (2001).

8. See HANS KELSEN, THE LAW OFTHE UNITEd Nations: A CRITICAL ANALYSIS OF ITS FUNDAMENTAL PROBLEMS 727 (1951) (He argues for maximum discretion). 
of bona fides, ${ }^{9}$ the principle of due process, ${ }^{10}$ the norms of $j u s$ cogens, as well as the purposes and principles of the U.N. Charter. ${ }^{11}$ Such issues are hotly debated, particularly in relation to the Security Council's coercive action against Libya, and Libya's attempt to question the legality of this action before the International Court of Justice. ${ }^{12}$ Although the case has not yet proceeded to the merits, and may never do so given the trial of the two Libyan agents suspected of the Lockerbie bombing, ${ }^{13}$ the issue is of profound significance for collective security law. An assertion of legal review over the most jealously guarded element of Security Council discretion would indeed establish the reality of collective security law. The existence of discretion is not inconsistent with the idea of the rule of law. It is perfectly possible to state that discretion must be exercised in accordance with the law.

Beneath this level of primary constitutional norms, we can evaluate the application of collective security mechanisms in legal terms, tracing them back to their source, normally within the provisions of constituent treaties of international organizations. Law is more secure at this secondary level since it is not as pressured by political considerations, though they must not be underestimated. Collective security action may take the form of peaceful settlement (or Chapter VI processes in U.N. Charter terms), or coercive action in the form of economic or military measures (Chapter VII action).

Furthermore, institutional development within the U.N. and other entities operating in the field has led to the implication and assertion of other powers. These include the creation of a consensual military option in the form of a peacekeeping force (sometimes labelled "Chapter VI1/2" action) as well as the more controversial use of international criminal tribunals in a collective security context. Fierce debate is still to be found at this level of legal analysis, for example in the discussion of whether international criminal tribunals can actually contribute to international peace, and whether the Security Council has the power to create such tribunals. ${ }^{14}$

The diversity of views on what constitutes collective security is interesting in itself since it reflects profound uncertainty. In a sense this is partly a product of the fact that collective security is a voyage into the

9. See generally Thomas Franck, The Bona Fides of Power, the Security Council and Threats to the Peace, 240 HAGUE RECUEIL 189 (1993).

10. See Prosecutorv Tadic, Case No. IT-94-1-AR72, 2 Oct.1995, para. 18 (Judge Sidhwa dissenting).

11. See R. Cryer, The Security Council and Article 39: A Threat to Coherence?, $1 \mathrm{~J}$. ARMED CONFL. L., 161 (1996).

12. See generally Lockerbie cases (provisional measures), 1992 I.C.J. Rep. 3; (preliminary objections), 1998 I.C.J. Rep. 9.

13. See Her Majesty's Advocate v. Al Megrahi, 40 I.L.M. 582 (2001).

14. See, e.g., Colin Warbrick, The United Nations System: A Place for Criminal Courts?, 5 Transnat'L L. \& ConTEMP. PROBs. 237 (1995); Timothy D. Mak, The Case Against an International War Crimes Tribunal for the Former Yugoslavia, 4 INTL. PEACEKEEPING 536 (1997). 
unknown in that it transcends the view that international society is essentially horizontal and consensual and can have no effective system of regulation or governance. We may have seen the erosion of this in certain areas, economics, human rights even, but to argue that such regulation has or can evolve in relation to the ultimate expression of high politics - the use of military power - automatically attracts accusations of "idealism" or "utopianism."

Indeed, to talk about collective security - and more so when talking about a collective security system - we are already assuming some sort of order, some sort of regulation perhaps. Law is presumed to exist, though it is not necessarily inherent in a collective security system, given that it is feasible to build an order on political foundations. However, such a political order is unstable, allowing a tremendous amount of change, often violent, as political considerations alter.

Maybe it is too much to expect law and mechanisms created by legal means to govern or regulate the use of military force in international relations, though the continuing normative force of the basic rule prohibiting the threat or use of force should not be underestimated. An absolute legalist and institutionalist vision does appear to be an exercise in utopianism. However, the opposite vision offered by the pragmatic or realist view of international relations of a brutal interplay of political interests and power sometimes disguised in normative language itself seems unrealistic given the time and energy states devote to justifying their actions, even their transgressions, not simply politically but legally.

But, it may be suggested that the current flexible use of purportedly legal justifications - for example the prosecution of a so-called global war against terrorism - suggest that we are living in a realist world. In the Middle East we are faced with a choice of trying to settle the conflict by the application of what Morgenthau labelled in 1946 as the "old diplomacy" based on balancing political interests or what he called the "new diplomacy" based on law embodied in the U.N. ${ }^{15}$ The exclusion of the U.N. from peace negotiations and the total reliance on the skewed power and influence of the United States is another indication of the current weakening of law and the rise of politics. But this has happened in the past. During the Cold War, the Soviet Union was notorious for playing fast and loose with concepts of international law in order to justify its hemispheric hegemony. The United States was more subtle in its deployment of legal arguments, but was, ultimately, no more convincing. The balance between law and politics is in constant flux, and even though law is in decline at the moment, this does not mean that it is dead or that it will not reassert itself in the future.

Both visions - realist and legalist - are offered in the literature on collective security. Indeed, the global collective security system embodied in the U.N. can be analyzed as an alliance of realist balance of power 
considerations (in the shape of the permanent five of the Security Council with their veto power) within an institutionalist legal framework. ${ }^{16}$

Brierly pointed out in 1946 that the presence of the veto is a significant, perhaps fatal, flaw in the constitutional edifice of the U.N. Charter. He further argued that the much derided League system may have been a more honest attempt to shape a collective security mechanism suited to a society of states, based as it was on principles of unanimity and voluntarism. "[B]efore international institutions can be raised from the co-operative to the organic type ... we need a society far more closely integrated than the society of states is to-day." The League failed, according to Brierly, not because of weaknesses in the design of the organization, but in the failure of states to fulfill their obligations under the Covenant.

Nevertheless, the U.N. has survived, although largely ineffective during the Cold War. Though a minority of member states breached the fundamental U.N. Charter provision prohibiting the use of force, and the permanent members ignored the limited restraints that do exist on their right of veto, ${ }^{18}$ the Charter has survived, though modified in certain respects by practice that has been accepted as normative. ${ }^{19}$

Furthermore, although powerful states chose to ignore the Charter in many instances, the idea of the U.N. as a mechanism for collective security has survived and its activities in the field have increased dramatically since the beginning of the 1990s. Powerful states cannot afford to be outside the U.N. This is illustrated historically by the temporary Soviet absence from the Security Council in 1950, an absence that enabled the Security Council to authorize military action against North Korea. ${ }^{20}$ However, while powerful states remain (for the moment) members of the U.N., they, on occasions, act outside it even in the more proactive post Cold War era, or they claim to be acting in support of it without clear U.N. authority. Weaker states, too, find a certain sanctuary within the U.N., though this is as much a product of economic factors and the fact that they, at least in the General Assembly, can make their voice heard, ${ }^{21}$ as it is about receiving protection under the collective security umbrella.

It is clear then that in collective security matters the law is not determinative, at least in a formalist sense. In the real world to achieve

16. See A. Todd, The Evolution of the International Executive: Reform of the U.N. Security Council (2001) (unpublished Ph.D. thesis, University of Nottingham).

17. J.L. Brierly, The Covenant and the Charter, 23 BRIT. Y.B. OF INT'LL. 83, 92 (1946).

18. See U.N. CHARTER art. 27, para. 3; WHITE, supra note 3, at 8-11.

19. For example, the practice that does not equate an abstention with a veto under U.N. CHARTER art. 27, para. 3, see the Legal Consequences for States of the Continued Presence of South Africa in Namibia (South West Africa) notwithstanding Security Council Resolution 276 (1970), 1971 I.C.J. Rep. 22 (June 21).

20. See U.N. SCOR 83rd Sess., 474th mtg. (1950).

21. But see V.S. Mani, The Role of Law and Legal Considerations in the Functioning of the United Nations, 35 INDIAN J. INT'L L. 91, 115 (1995). 
solutions we cannot simply apply the law to the facts, although it is an exercise that the academic international lawyer loves to engage in, as students of international law know all too well. On the other hand, it is too simplistic to dismiss law as irrelevant. "Arguing that normative factors are either irrelevant or only marginally relevant to Security Council action undermines the degree to which any social action, including international activity, makes constant reference to normative codes, rules or principles." ${ }^{, 22}$ Although there may be great debate and controversy about the content of these rules and principles, their presence and usage signifies that the "controversy is therefore normative $\ldots$ and not empirical." ${ }^{23}$

Powerful states may choose to step outside the normative framework on occasions. This is not just a recent phenomenon - witness the Cuban Missile Crisis in 1962 and the NATO bombings of the Federal Republic of Yugoslavia (FRY) in 1999. However, those states normally try to justify their actions either as actually coming within the institutional legal framework, or they try to stretch the framework, or they claim a customary basis for their action, or sometimes they simply have to admit that in all honesty this is an exceptional circumstance that does not create a precedent for the future. Law is confirmed or re-shaped by these claims and the responses of other states and actors to them. In effect the legal rules claimed to be applicable in any given conflict or dispute are put in the international spotlight, and either survive intact or are modified. Thus collective security law exists somewhere between the formalist and realist positions. However, as I will argue in the conclusion, we must not be too ready to assume that the law has changed when we are faced with behaviour that appears to disregard law even if that behavior is claimed to be reflective of a new law.

\section{ACTORS WITHIN THE UNITED NATIONS: POWERS AND LEGITIMACY}

The U.N. is the main actor in the field of collective security. Although there are many other organizations in the field - regional (for example the Organization of American States -OAS, the European Union - EU, and the African Union - AU), sub-regional (for example the Economic Community of West African States - ECOWAS), defence (for example the North Atlantic Treaty Organization - NATO), and security (for example the Organization on Security and Cooperation in Europe - OSCE) - the U.N. is the only global actor.

While the Security Council has "primary responsibility" for international peace and security, ${ }^{24}$ the other organs (the General Assembly, the International Court of Justice and the Secretary General) have subsidiary competence, often

22. See Koskenniemi, supra note 4 , at 468.

23. Id. at 469.

24. See U.N. Charter art. 24, para. 1. 
overlooked in the cascade of activity emerging from the Security Council with the end of the Cold War. This activity has caused international lawyers great concern. While applauding increased effectiveness and enforcement, lawyers have been concerned with issues of legality, legitimacy, and selectivity. ${ }^{25}$

In particular, the failure of the Security Council to act effectively - for example in Rwanda in 1994, Srebrenica in 1995 and Kosovo in 1999 - when faced with clear threats to the peace - could be said to be a major factor which has endangered the whole collective security edifice. The U.N. looks increasingly irrelevant. In the events that followed September 11, 2001, the Security Council condemned the atrocity and took non-forcible measures, ${ }^{26}$ but it has not in any way regulated the United States' military response. ${ }^{27}$ Such a vision of the U.N. as being bypassed by major powers must be balanced against the fact that the longer-term solutions to Bosnia, Kosovo, and possibly Afghanistan, are left in the hands of the U.N. The UN appears irrelevant but it is not. Indeed, the presence of protectorate-type administrations in Bosnia, Kosovo, and East Timor represent a new development in the power of the U.N. It is, in effect, the government of these countries. ${ }^{28}$ Furthermore, its antiterrorist measures applicable within all member states taken in response to September 11, 2001 look very much like global governance much more so than its previous sanctions regimes which were targeted at individual states. ${ }^{29}$

While the U.N. is subject to criticism when it does not act, it is also subject to criticism when it does. With the end of the Cold War in the late 1980s, the Security Council has flexed its muscles in a variety of ways. Sometimes, this has been legally problematic, more often there have been question marks over the legitimacy of individual actions, and more fundamentally the issue of the legitimacy of a fifteen member organ (with a built-in pentarchy) "dictating" to the membership of one hundred ninety-one states. Sometimes this dominance narrows even further so that in the case of sanctions against Iraq, it is the refusal of two states (the U.S. and the U.K.) that prevents the lifting of the embargo. ${ }^{30}$

The concentration of governance in the hands of the Security Council is of direct concern to collective security law. While being conceived primarily as an executive body "bestowed with policing power and the capacity to use

25. See generally T.M. Franck, The Power of Legitimacy Among Nations (1990).

26. U.N. Security Council Resolution, S/Res/1368 (Sept. 12, 2001), U.N. Security Council Resolution, S/Res/1373 (Sept. 28, 2001).

27. The Security Council did authorize an International Security Assistance Force following the defeat of the Taliban. See U.N. Security Council Resolution, S/Res/1386 (Dec. 20, 2001). But this did not end the U.S.-led military action in that country.

28. Ralph Wilde, From Danzig to East Timor and Beyond: The Role of International Territorial Administration, 95 AM. J. INT'L. L. 583 (2001).

29. See Eric P. J. Myjer \& Nigel D. White, The Twin Towers Attack: An Unlimited Right to Self-Defence?, 7 J. CoNFl. SECURITY L. 1, 2 (2002).

30. See David D. Caron, The Legitimacy of the Collective Authority of the Security Council, 87 AM. J. INT'L. L. 552, 587 (1993). 
coercive force in the form of military and economic sanctions," ${ }^{\prime 31}$ the Security Council has also acted in judicial and legislative ways. In liberal democratic theory, the failure to separate these powers in different organs (executive, judicial and legislative) is seen as a recipe for abuse of power, given that this may lead to one organ making law, applying the law and enforcing the law.

Although the Great Powers (the Permanent Five or P5) may have wanted to create an organization based on order or power, they failed to eradicate all references to justice and authority in the U.N. Charter. More importantly those powers made minor concessions to the smaller states, which wanted the General Assembly to have some competence to deal with economic, social and humanitarian matters. These matters had the potential, within a developing constitutional order, to spill into the Security Council's main area of competence. The result according to Koskenniemi is that " $[t]$ he Organization is neither simply a policeman nor a Temple of Justice." 32 During the Cold War, with the Council (the Police) largely unemployed, matters were dealt with in the Assembly (the Temple). They were dealt with not simply in terms of order but in terms of the injustices felt by the majority of members. The result was that "[t]he 'tyranny' of the Great Powers was overruled by the 'tyranny' of the majority." 33 The Assembly, though much weaker in terms of powers, did occasionally try to maintain order in the absence of an effective Security Council. It did this by recognizing that it had recommendatory enforcement powers in the (in)famous Uniting for Peace Resolution of $1950,{ }^{34}$ and by creating the first peacekeeping force to help resolve the Suez crisis in $1956{ }^{35}$

However, with the end of the Cold War the position has been changed - "[i]t is not the Assembly that is trying to deal with the problem of order; the Security Council is attempting to deal with the problem of international justice." ${ }^{\text {"6 }}$ Koskenniemi argues against this development in essence by stating that considerations of justice (embodied in wide conceptions of peace and security) are not the concern of the Police but of the Temple. He warns us that " $[t]$ he peace of the police is not the calm of the temple but the silence of the tomb." 37

The legality of the Uniting for Peace Resolution is regarded by many as a theoretical problem given that issues of order (and, increasingly, justice) are now in the hands of the Council. However, there are arguments that in

31. Keith Harper, Does the United Nations Security Council Have the Competence to Act as Court and Legislature? 27 N.Y.U. INT'L. L. \& POL 103, 107 (1994).

32. Martti Koskenniemi, The Police in the Temple: Order, Justice and the U.N.: A Dialectical View, 6 EUR. J. INT'L. L. 325, 328 (1995).

33. See id. at 337.

34. See U.N. GAOR, 5th Sess., 302d plen. mtg., U.N. Doc. A/Res/377 (1950).

35. See Mone Ghali, The United Nations Emergency Force I: 1956-1967 in W.J. DuRCH (ed.), The EVOLUTION OF U.N. PEACEKEEPING, 104 (London, Macmillan, 1994).

36. Koskenniemi, supra note 32 , at 341.

37. See id. at 348. 
exceptional cases, it should be revived. Arguably this should have happened in the Kosovo crisis, where the Security Council again appeared to be deadlocked. ${ }^{38}$ The arguments in favor of NATO bombing of the FRY in 1999 seemed to be predicated on the need to uphold human rights and to prevent grave injustices - ideal issues to be considered by the General Assembly. The fact that General Assembly approval was not sought undermines the credibility of collective security law. Further, rhetorical claims to be acting on behalf of the "international community," without grounding those actions within concrete manifestations of that community, constitute a serious erosion of the fragile foundations of peace.

Collective security law loses its credibility if it fails to bring powerful actors within its procedures and mechanisms. Paradoxically episodes like Kosovo and Afghanistan, while eroding collective security law may be viewed as bolstering much wider claims for states to use force under customary international law. Claims to controversial customary rights such as humanitarian intervention are growing, as are claims to extend the scope of the existing right of self-defence.

When do terrorist actions give a state the right to exercise self-defence; and if triggered how far does that right extend? The United States has undertaken actions which seem to suggest that answers to these questions depend entirely on the subjective, strategic considerations of the victim state. The danger of creating such precedents is amply shown by Israel's current disastrous war against terrorism. The fact that Israel views its war as internal is irrelevant since the United States' stance on terrorism justifies internal repression as well as external aggression.

Further pressure on collective security law is exerted by states claiming to act in support of Security Council resolutions. This claim is sometimes combined with customary rights so that in Kosovo we had some NATO states claiming the right of humanitarian intervention, though most took the position that these actions were somehow justified under existing Security Council resolutions, though none authorized the use of force in clear language. ${ }^{39}$

Though the initial Security Council authorization given in $1990^{40}$ to use force against Iraq was lawful, there is much greater doubt about the legality of continued military actions by the dwindling Coalition after the conflict had ended in March 1991. ${ }^{41}$ This started with the protective measures taken by western forces in Kurdish northern Iraq in April 1991, although there was no

38. Nigel D. White, The Legality of Bombing in the Name of Humanity, $5 \mathrm{~J}$. CONFL. \& SECURITY L. 27 (2000).

39. See generally U.N. Security Council Resolution, S/Res/1199 (Sept. 23, 1998); Nico Krisch, Unilateral Enforcement of the Collective Will: Kosovo, Iraq and the Security Council, 3 MAX PLANCK Y.B. OF U.N. L. 59 (1999).

40. See U.N. Security Council Resolution, S/Res/678 (Nov. 29, 1990).

41. See Nigel D. White, The Legality of the Threat of Force Against Iraq, 30 SECURITY DiALOGUE 75 (1999). 
clear Security Council authority for such an operation. ${ }^{42}$ The claiming of such authority by those states using force has become part of the diplomatic and legal exchanges in the U.N. This has not only been the case with continued military action (mainly by the U.S. and the U.K.) as regards Iraq but also the action taken by NATO against the FRY in 1999. Action taken "in support" of Security Council resolutions has become a controversial legal claim so much so that it is sometimes combined with claims of customary rights allegedly belonging to the states taking the action such as self-defence or, much more controversially, humanitarian intervention. Again we appear to be heading towards a disintegration of the system - in that it seems that law does not shape the debate, it is simply a tool in the hands of the powerful states. ${ }^{43}$

Such claims, as they get wider and wider, and further removed from the basic principles governing the use of force in the U.N. Charter, will lead to a situation of lawlessness, though we are not there yet. The presence of additional or wider customary rights is not necessarily an anathema to the idea of collective security, though it may be argued that if these rights are recognized as wide-ranging and subjective, then it is no longer possible to talk about collective security. If this is the case, while not completely returning to the pre-1919 period of a virtually unlimited right to go to war, international relations will have reached a point where force is permitted in so many instances that the regulation of it no longer makes any sense.

\section{Collective Security OUTSIDE THE U.N.}

The credibility of collective security law is also dependent on there being workable legal principles governing the relationship between the U.N. and other actors in the field of collective security - regional, sub-regional, defence and security organizations. In considering the relationship between the U.N. and these entities it is pertinent to ask whether we have a collective security system in which universal and regional entities act in harmony to contribute to greater collective security, or do we have competition between them? This is the issue on which Hilaire McCoubrey, along with Justin Morris, has made a significant contribution. ${ }^{44}$

The Kosovo question raised the issue of the use of force by regional agencies. The U.N. Charter seems quite clear on these matters. While collective defence is preserved for such organizations, ${ }^{45}$ any enforcement action beyond the purely defensive, to deal with a threat to the peace, requires

42. See U.N. Security Council Resolution, S/Res/688 (Apr. 5, 1991).

43. See Jules Lobel \& Michael Ratner, Bypassing the Security Council: Ambiguous Authorizations to Use Force, Cease-Fires and the Iraqi Inspection Regime, 93 AM. J. INT'L. L. 124,153 (1999).

44. See Hilaire McCOUBREY \& JUSTIN MORRIS, REgional PEACEKEEPING IN THE POSTCOLD WAR ERA (2000).

45. See U.N. CHARTER art. 51. 
the authorization of the Security Council. ${ }^{46}$ NATO is an international organization consisting of nineteen member states, which acts on the basis of consensus. Should such an organization be limited by the use or threat of the veto in the Security Council, particularly when NATO's intent is to prevent crimes against humanity being committed $?^{47}$ The belief that regional organizations should not be so limited is not confined to NATO, but is also evident in the case of the ECOWAS, a sub-regional organization. ECOWAS has intervened in civil wars in Liberia and Sierra Leone without clear Security Council authority, and has adopted a Protocol that purports to allow it to do this. ${ }^{48}$ The new Constitutive Act of the African Union of July 11, 2000, states as one of its principles " $[t]$ he right of the Union to intervene in a Member State pursuant to a decision of the Assembly in respect of grave circumstances, namely: war crimes, genocide and crimes against humanity.,49

Such claims to collective regional intervention are sometimes bolstered by additional assertions of a customary right to humanitarian intervention, or by the consent of the government (if this can be obtained).$^{50}$ The fact that regional organizations feel the need to base their interventions on (controversial) customary grounds rather than solely on the basis of their own constituent treaties or documents is a sign of the weaknesses that exist in the legal basis of these actions. However, when taking account of the motives of these organizations - principally but not exclusively the desire to prevent human rights atrocities - should not collective security law reflect their demands?

It could be argued that just as Article 51 of the U.N. Charter was inserted to ensure that regional organizations had the right to defend themselves in emergency situations when confronted with an armed attack, so should such organizations be allowed an emergency right to defend human rights from serious violations. ${ }^{51}$ However, such a recognition would have to be built into the legal framework of the U.N., not necessarily by formal amendment but perhaps by General Assembly resolution adopted by consensus. Without universal recognition, regional humanitarian military actions will lack legitimacy as well as legality. Furthermore, the General Assembly would have to set precise pre-requisites for regional humanitarian intervention, otherwise, to paraphrase Simma, the genie of regional self-authorization will be let out of

46. See U.N. CHARTER art. 53, para. 1.

47. See, e.g., Bruno Simma, NATO, the UN and the Use of Force: Legal Aspects, 10 EUR. J. INTL. L. 15, 29 (1999) (statement made in 1998 by U.S. Deputy Secretary of State Strobe Talbott - "we must be careful not to subordinate NATO to any other international body.")

48. See Ademola Abass, The New Collective Security Mechanism of ECOWAS: Innovation and Problems, 5 J. CONFL. SECURITY L. 211 (2000).

49. See Constitutive Act of the African Union, July 11, 2000, art.4(h), available at $\mathrm{http} / / / \mathrm{www} . \mathrm{au} 2002$.gov.2a/docs/key_oau/au_act.htm (last visited Sept. 25, 2002).

50. See Christian Walter, Security Council Control Over Regional Action, 1 MAX PLANCK Y.B. OF U.N. L, 129 (1997).

51. Id. at 167. 
the bottle. ${ }^{52}$ Nevertheless, the increasing need to utilize regional mechanisms to achieve a better system of collective security is pointed out by McCoubrey and Morris:

It is rather the case that the end of the Cold War has created a positive opportunity for the regeneration of a genuine global collective security system in which the UN, manifestly, cannot be expected itself to be the unique source of peace support action, but will function rather as the mechanism through which a variety of resources will be deployed to that end in cases of need. ${ }^{53}$

The challenge for the U.N. and regional actors is to produce an acceptable legal framework that allows for regional initiatives and actions but at the same time regulates them.

Cooperation between the universal and regional levels has occurred. This was seen in Bosnia after Dayton in 1995, and in Kosovo after Serbian withdrawal in 1999, where the NATO military operates under U.N. authorization, alongside U.N. and other (e.g. OSCE) civilian components. ECOWAS and the U.N. have cooperated in both Liberia and Sierra Leone after initial uncertainty. The world after September 11, 2001, though, does not seem to offer much prospect of further cooperation. Indeed, it seems to represent a profound move away from collective security organizations towards unilateralism.

NATO was at the heart of the operations against the FRY in 1999, though the military force applied was dominated by the United States. NATO was not utilized in a physical way in the case of Operation Enduring Freedom against Afghanistan, though Article 5 of its Treaty was invoked. ${ }^{54}$ It seems odd that NATO was in operation in a collective security fashion alien to its origins against the FRY in 1999, but not in a purportedly defensive operation, closer to its raison d'être, against Afghanistan in 2001. In reality the war against terrorism is not a response to an armed attack or a series of armed attacks stretching back to Lockerbie but to a continuing threat to the peace represented by terrorist activities. In effect the Security Council recognized this in its resolutions following September 11, 2001, when it found a threat to the peace but did not clearly find that the attack constituted a breach of the

52. See Simma, supra note 47, at 20.

53. MCCOUBREY, supra note 44, at 243. See also David O'Brien, The Search for Subsidiarity: The UN, African Regional Organizations and Humanitarian Action, 7 INT'L. PEACEKEEPING 57 (2000).

54. See Myjer \& White, supra note 29 , at $8-9$ (citing statement by NATO Secretary General Lord Robertson, on Oct. 2, 2001). 
peace or act of aggression. ${ }^{55}$ The Security Council was unable or unwilling to exercise its primary responsibility to deal with threats to the peace, instead the United States and its ally, the United Kingdom, have acted. This represents the greatest challenge to collective security law.

In terms of the formal legal framework provided by the U.N. Charter, states are not permitted to take military actions except in self-defence or if authorized by the U.N. ${ }^{56}$ What has happened in Iraq since the cease-fire in 1991, and Afghanistan since 2001, is that the United States, sometimes acting along with its allies, is taking action to deal with threats to its peace. Such a condition, being subjective and unilateral, is manifestly worse than a system, which despite its clear deficiencies, is at least an attempt at collective security to deal with threats to the peace. Kosovo is different in that it was more a product of altruistic and multilateral action. It had a greater legitimacy but the failure of NATO to seek General Assembly support undermined this, and the confused claims to legality render it a dubious precedent. ${ }^{57}$

\section{CONCLUSION}

The challenge faced by collective security law in attempting to regulate violent actions by states is encapsulated by the statement of Dean Acheson, then former United States Secretary of State, when he considered legal objections to the United States' quarantine of Cuba in 1962. Acheson stated "[t]he power, position and prestige of the United States had been challenged by another state; and law simply does not deal with such questions of ultimate power - power that comes close to the sources of sovereignty." 58 The U.N. system protects such power to a great extent by elevating the P5 to a position where they cannot normally be subject to enforcement action. However, with such power comes responsibility. If the members of the P5 acting within the Security Council disable that body, preventing it from carrying out its responsibility for peace and security, then the U.N. system loses its credibility. Pressure from regional bodies, ad hoc coalitions, and single states then mounts to allow them greater freedom of action in the sphere of collective security.

55. Although the U.N. Security Council Resolution 1368 (Sept. 12, 2001) confirms in general terms the right of self-defence, it only determined that the terrorist attacks amounted to a threat to the peace. See S.C. Res. 1368 (Sept. 12, 2001). In contrast the Security Council affirmed the right of self-defence "in response to the armed attack by Iraq against Kuwait" in S.C. Res. 661 (Aug. 6, 1990), following a determination of a breach of the peace in S.C. Res. 660 (Aug. 2, 1990). See Myjer \& White, supra note 29, at 5-7.

56. U.N. CHARTER arts. 42, 51, 53.

57. See H.C. Select Committee on Foreign Affairs, Fourth Report, June 7, 2000, paras. 124-44. See also International Commission on Intervention and State Sovereignty, The Responsibility to Protect, paras. 6.7-6.9 (2001), available at http://www.iciss.gc.ca/report-e.asp (last visited Aug. 27, 2002).

58. Dean Acheson, Proceedings of Am. Soc. Int'l L. at its Fifty-fifth Annual Meeting, 14 AM. SOCIETY INT'L L. PROC. 14-15 (1961-63). 
Collective security is beset by tensions - tensions between universal and regional action, between collective and unilateral action, as well as those that exist between institutional legal frameworks and customary international law, and above all, as Acheson's statement shows, between politics and law.

The structures and rules that form the corpus of collective security law are inevitably rudimentary in a field of international relations that is dominated by sovereign states. Their weaknesses contribute greatly to the impression that the world, or at least a significant part of it, is continually balancing on the brink of disaster.

With the horrific attacks that were launched against the United States on September 11,2001, when three hijacked civilian airliners were flown into the World Trade Center and the Pentagon, we seem to have moved closer again to that edge of lawlessness. The United States' response seems not to be based clearly on the established principles governing self-defence, although the action itself and the reaction of the world may lead to a re-shaping of that law. It is not solely a response to an armed attack, it is mainly a response to a threat to the peace caused by international terrorism - a collective security issue which has only been partially dealt with by the U.N.

What I have outlined is a system that continually shifts between politics and law. The fact that we have undoubtedly moved into a situation in which politics dominates does not mean that we cannot step back from the edge of lawlessness. The majority of states should be more prepared to criticize the United States and its allies - the General Assembly should attempt to reassert itself as the Temple of Justice, condemning illegal uses of force by states as well as terrorists without fear or favor as it tended to do during the Cold War. Otherwise the opportunity will be taken to argue that acquiescence is a condonation of actions taken, thereby giving rise to custom simply permitting powerful states to use force whenever their strategic interests are at stake, a proposition which must be far from the truth. Why would developing or weak states agree with this? ${ }^{59}$ A cynic might argue they have no choice but to say nothing (which is not the same as agreeing) for if they object then they are in effect deemed to be siding with the terrorists. This is what President Bush made clear on November 6, 2001, when he stated that those nations not "for" the United States were "against us." ${ }^{100}$ Despite the difficulty for the majority in making its voice heard, too much weight must not be attached to the voices and actions of the minority, no matter how powerful. Furthermore, the U.N. is not irrelevant, indeed it remains the only organization with sufficient legitimacy to pull the world back from the chasm of lawlessness that it is yet again looking down into. The U.N. should not compromise its laws and

59. But see Michael Byers, The Shifting Foundations of International Law: A Decade of Forceful Measures against Iraq, 13 EUR. J. INT'L. L. 21 (2002). See also Independent International Commission on Kosovo, The Kosovo Report, 172 (2000).

60. BBC NEws, Bush urges anti-terror allies to act, Nov. 6, 2001, available at news.bbc.co.uk/hi/...orld/europe/newsid_1642000/16242130.stm. 
principles in the face of increasing violence committed by states as well as non-state actors. Above all, we must not forget the idea to which Hilaire McCoubrey dedicated himself - the idea that peace can be achieved through law. 
